Izabela Wiencek

Warszawa

\title{
Stare druki - o potrzebie portalu informacyjnego i ogólnopolskiej bazy proweniencji
}

Ktoś może zapytać: jaki jest pożytek ze starych druków ${ }^{1}$, kilkusetletnich, dawno zdezaktualizowanych książek, napisanych po łacinie, po grecku, w dawnych dialektach niemieckich, francuskich, włoskich, w niezrozumiałej polszczyźnie? A nawet jeśli znamy ów archaiczny język, przeszkodę może stanowić trudna w odczytaniu czcionka, ze skomplikowanymi skrótami i fantazyjnie połączonymi literami. Jak często nie można się porozumieć ze starą książką! Budzi ona jednak szacunek jako przedmiot powstały przed wiekami i przez to cenny. Kustosze zbiorów specjalnych wydatnie przyczyniają się do umocnienia tego wizerunku: noli me tangere! napominają w imieniu książki, nie tykaj mnie, i umieszczają ją troskliwie w gablocie, gdzie staje się „obiektem wystawienniczym”. Ale to dotyczy tylko wybranych, najbardziej interesujących egzemplarzy; tymczasem stare woluminy nie zawsze są piękne i okazałe, często przedstawiają smutny widok, ze zniszczonymi, zalanymi, spleśniałymi kartami, oderwanymi okładkami. Trafia się też słabe liternictwo i ilustracje, złej jakości papier i niechlujny skład. Książki tworzące Narodowy Zasób Biblioteczny bywają bardzo nieatrakcyjne wizualnie, w dodatku narażając użytkownika na kontakt z jaką́s niezidentyfikowaną bakterią lub grzybem.

„Co to znaczy in folio?” zapytał młody człowiek odwiedzający pokaz dawnej książki zorganizowany przez Gabinet Starych Druków BUW w czasie Nocy Muzeów dwa lata temu. „Pojawia się to sformułowanie w Kodzie Leonarda da Vinci - 'osiemnaście stron in folio'2. Czy może mi to Pani wyjaśnić?" Wśród licznych książek wytłoczonych ręcznie, na po-

${ }^{1}$ Przypomnijmy, że w Polsce termin „stary druk” stosuje się do wydawnictw, które się ukazały od powstania druku (ok. 1450) do 1800 roku włącznie. Niektóre europejskie biblioteki naukowe skłaniają się do przesunięcia tej granicy: CERL (Consortium of European Research Libraries) jako datę graniczną przyjął rok 1830.

${ }^{2}$ D. Brown, Kod Leonarda da Vinci, Warszawa 2005, s. 381. 
kazie były i folia czyli tzw. „dwójki” - wielkie tomy oprawne w deskę i skórę świńską, posadowione wygodnie na specjalnych pulpitach. Można było pokazać na przykładach, czym się różni „dwójka” od „czwórki” i skąd wzięła się ta terminologia, biorąca swój początek od rozstawu ramion pracownika XV-wiecznej papierni. Takie pytania i cieszą i martwią - cieszą, bo zainteresowanie tematem kilkusetletniej książki istnieje; martwią, jeśli występuje ono w wyniku fascynacji literaturą wątpliwej jakości, gdzie „stare pożółkłe księgi” są przedstawione w mroku teorii spiskowych, jako przekaźnik wiedzy tajemnej, heretyckiej, budzącej grozę. Jak wyplątać czytelników z tej fałszywej postmodernistycznej papki?

Myślę, że warto na wstępie, nieco prowokacyjnie, przywołać te dwie, trochę sprzeczne, trochę zbieżne wizje, jakie budzi dawna książka w niejednym konsumencie wydań nowych, pachnących farbą drukarską oraz odbiorcy współczesnych mediów. I nie mówimy tu o zdecydowanym antyczytelniku, ale o wykształconym, poszukującym odbiorcy, który zadaje pytanie: co ja tu znajdę dla siebie?

Studenci bibliotekoznawstwa - osoby, które powinny być ex definitione zmuszone do zetknięcia się z wytworem dawnej oficyny drukarskiejczęsto tylko pobieżnie zapoznają się na zajęciach $\mathrm{z}$ historią drukarstwa. Zdają potem egzamin magisterski, nie mając doświadczenia w obcowaniu z książką zabytkową. Nigdy nie widzieli np. książki renesansowej: nie sprawdzili sprężystości wytworzonego ręcznie papieru, nie przyjrzeli się dokładnie rysunkowi czcionki, nie zbadali, jakie proporcje zajmują parateksty (listy dedykacyjne, przedmowy, wstępy) względem tekstu właściwego. Szkoda, zwłaszcza jeśli biblioteka macierzystej uczelni, w której znajduje się kilkanaście tysięcy XVI-wiecznych edycji, ma swą siedzibę tylko o kilka przecznic od sali wykładowej.

A studenci historii, polonistyki, filologii klasycznej, orientalistyki, romanistyki, italianistyki, innych filologii... Wiedza o dawnej książce przydałaby się z pewnością adeptom historii sztuki, grafiki (również jako inspiracja artystyczna), archeologii, konserwacji, oraz wszelkich dyscyplin, których dzieje sięgają kilkuset lat, a ich zmieniający się obraz można prześledzić za pośrednictwem starych druków. Wiadomo, że na wielu wydziałach odbywają się zajęcia $\mathrm{z}$ dawnej książki, jednak wydaje się, że wciąż jest ich za mało.

Dla badacza specjalizującego się w literaturze dawnej archaiczny język będzie czytelny, ale może nieznany mu będzie ikonograficzny przekaz towarzyszącej tekstowi ilustracji albo okoliczności ukazania się konkretnego wydania. Literaturę dotyczącą edycji będzie znał pracownik oddziału starych druków; na temat ryciny wyczerpująco wypowie się historyk sztuki zatrudniony w oddziale ikonograficznym (rycin). Jak do- 
prowadzić do spotkania różnorodnej wiedzy, która funkcjonując osobno nie daje pełnego rozumienia wieloaspektowego wytworu kultury, jakim jest dawna książka? Jak osiągnąć interdyscyplinarną, humanistyczną jedność, a nie poprzestawać na oderwanych konstatacjach?

Powyżej była mowa o przeszkodach, które uniemożliwiają owocne spotkanie ze szczególnym rodzajem zabytku, jakim jest dawna książka. Zaawansowanego technicznie odbiorcę różnych mediów, mniej obeznanego z historią, powstrzyma stereotyp i uprzedzenia, które z niego wynikają; studenta, któremu wręcz należy się wiedza o starych drukach, odcina od ich bezpośredniego poznania brak praktyk bądź chociażby pokazów w odpowiednich oddziałach bibliotek naukowych; fachowca-badacza zaś ogranicza nadmiar i rozproszenie materiału, a także zawężenie własnej specjalizacji. Jego ogólna wiedza humanistyczna może być bardzo rozległa, ale wiadomo, że nie ma już szans na powrót do renesansowego ogarniania uniwersum nauki. Dawna książka, skupiając w sobie interdyscyplinarny materiał, stanowi teren badawczy dla wielu dziedzin. Nikt nie jest $\mathrm{w}$ stanie $\mathrm{z}$ jednakową ostrością dostrzec wszystkich jej aspektów. Jednak korzystając z dobrodziejstw „cyfrowego zwrotu w humanistyce", można się pokusić o stworzenie narzędzia, które pozwoli na zogniskowanie samej informacji o starych drukach - coś w rodzaju wielowątkowego przewodnika po libri illegibiles ${ }^{3}$.

\section{Stare druki - portal informacyjny}

W Polsce nie ma na razie mowy o przesunięciu granicy chronologicznej starego druku w kierunku XIX wieku. Książki i czasopisma wydane do 31 grudnia $1800 \mathrm{r}$. są w polskich bibliotekach naukowych wydzielone z głównego zasobu i znajdują się w oddziałach, zakładach bądź gabinetach starych druków. Dlatego wydaje się zasadne poświęcenie osobnego portalu książce tłoczonej ręcznie w XV-XVIII wieku. Poniżej sugerowana zawartość takiej strony:

1. Krótka historia książki drukowanej w Polsce

2. Słownik terminów

3. Zasoby starych druków

4. O badaniach nad dawną książką

5. Jak i gdzie szukać informacji? Katalogi, bazy, portale

${ }^{3}$ Tak określano w XVI wieku książki wydrukowane w wieku XV czyli inkunabuły, ze względu na nieaktualną, przesyconą średniowiecznym duchem treść i utratę walorów użytkowych. 
6. Literatura fachowa

7. Konferencje, warsztaty, wydarzenia

8. Antykwariat

9. Baza proweniencji (baza polskich sygnetów drukarskich, baza opraw, baza filigranów, ilustracji...)

10. Kontakt

Ad.1. „Krótka historia książki drukowanej w Polsce” - przedstawiona albo w jednym syntetycznym artykule albo za pomocą serii tekstów, prezentujących kolejne etapy rozwoju drukarstwa polskiego do 1800 roku. Wzorem takiej, najbardziej rozszerzonej wersji jest dwujęzyczny, holendersko-angielski portal Bibliopolis ${ }^{4}$, koordynowany przez Narodową Bibliotekę Holandii (Koninklijke Bibliotheek), poświęcony historii książki niderlandzkiej 1460-1910. Wprowadzono tu podział chronologiczny na pięć etapów: 1460-1585 (Rise and general dissemination), 1585-1725 (Hey-day as centre of world trade), 1725-1830 (Domestic orientation), 1830-1910 (Growth of the domestic market), 1910-heden (Mass product and cultural product). Każdy z nich omówiono w kilku bądź kilkunastu mini-artykułach, np. etap pierwszy obejmuje: 1. introduction; 2. letters (including letter design, typecasting and type foundries); 3. paper (including production, watermarks, paper trade); 4. formats/design of the text; 5. illustrations and decorations; 6. bookbinding (including bookbinderies). Artykuły są sygnowane nazwiskami autorów - czterdziestu zaangażowanych w projekt wybitnych historyków książki, związanych z uniwersytetami w Amsterdamie, Lejdzie, Nijmegen, Utrechcie. Zwracamy tu uwagę na owocną kooperację pomiędzy kustoszami zbiorów specjalnych a uniwersytecką kadrą naukowo-dydaktyczną. W sumie historia drukarstwa została omówiona w 158 tekstach.

Ad.2. „Słownik terminów”. Wszystkie newralgiczne terminy, używane w artykułach portalu Bibliopolis i dotyczące historii książki, odsyłają do specjalnego słownika. Na gruncie polskim sytuację komplikuje brak obligatoryjnych ustaleń terminologicznych, chociażby w odniesieniu do zdobnictwa książki (oprawa, ornamentyka tekstu) czy warstwy ikonograficznej druków (określanie przedstawień na rycinach) ${ }^{5}$. Terminologia, którą się posługujemy na podstawie $\mathrm{EWOK}^{6}$, też w wielu przypadkach

\footnotetext{
${ }^{4}$ Por.: www.bibliopolis.nl

${ }^{5}$ Więcej na ten temat: M. Cubrzyńska-Leonarczyk, I. Wiencek, Grafika polska w starych drukach - terra incognita? Z problemów rejestracji i opracowania, [w:] Metodologia, metoda i terminologia grafiki i rysunku. Teoria i praktyka, Warszawa 2013 [w druku].

${ }^{6}$ Od zeszłego roku, w ramach grantu Narodowego Programu Rozwoju Humanistyki, pod kier. prof. A. Żbikowskiej-Migoń, trwają prace nad nową Encyklopedia książki mamy nadzieję, że liczne problemy terminologiczne rozwiążą się wraz z jej publikacją.
} 
wymaga uaktualnienia. Przytoczmy chociażby takie przykłady: czy używany przez niektórych specjalistów termin „starodruk” jest uprawniony? Kiedy można posługiwać się terminem „cymelium”? Mówimy: „frontyspis” czy „frontispis”? Jak widać, często nie dysponujemy gotowym materiałem, łatwym do przeniesienia w przestrzeń wirtualną. Ale być może uruchomienie portalu przyczyniłoby się do doprecyzowania bądź określenia na nowo terminów odnoszących się do dawnej książki i tym samym wprowadzenia „wartości dodanej” na ten teren badawczy.

W zakładce „Słownik terminów” widzielibyśmy również narzędzie edukacyjne, polegające na przedstawieniu wybranych starych druków pod kątem ich morfologii (budowy). Zdjęcia kluczowych miejsc w książce (karta tytułowa, przedmowa, listy dedykacyjne, kolofon) można objaśnić za pomocą strzałek w taki sposób, aby każdy z elementów druku stał się czytelny, nieprzemilczany. Wydaje się bowiem, że niewiele mówiące jest zatrzymywanie się na ogólnym podsumowaniu, w rodzaju: „piękna drzeworytowa karta tytułowa". Warto objaśnić wszystkie szczegóły, nie tylko dotyczące cech wydawniczych książki, ale i indywidualnych (widoczne pieczątki, zapisy własnościowe, ślady konserwacji). Odrębność tych dwóch światów (książka wydrukowana i książka używana-posiadana), tak oczywista dla katalogujących, wymaga stanowczego objaśnienia. Wybrane terminy mogą być linkowane i prowadzić do wspomnianego wyżej słownika.

W formie najbardziej rozbudowanej, owo narzędzie mogłoby przybrać postać „książki interaktywnej”, w formie trójwymiarowej, obracalnej, przybliżanej, której karty można obracać, a nawet takiej, która sama czyta, co w niej zapisano (te trudno czytelne dukty i czcionki!), np. oznajmia: Sum clarissima supellex Iosephi Andreae Zaluski ${ }^{7}$. To może i nieco humorystyczna wizja przybliżania zabytku, ale skoro można przeżyć trzęsienie ziemi w Centrum Nauki Kopernik...

Ad. 3. „Zasoby starych druków”. Czy wiemy, ile obecnie znajduje się starych druków w Polsce? Niestety, nadal nie potrafimy tego precyzyjnie określić. Książki zabytkowe posiadają zarówno biblioteki państwowe (naukowe, uniwersyteckie, publiczne, instytucjonalne itd.), jak i kościelne, klasztorne oraz prywatni kolekcjonerzy. Nikt nie prowadzi statystyk uwzględniających wszystkie dane. Funkcję repozytorium informacji o edycjach wydrukowanych do 1800 roku, znajdujących się w bibliote-

7 „Jestem wybornym sprzętem [należącym do] Józefa Andrzeja Załuskiego”, zapis w książce wyd. w 1555 roku, Biblioteka Uniwersytecka w Warszawie (dalej cyt. BUW), sygn. Sd.602.1397. 
Izabela Wiencek

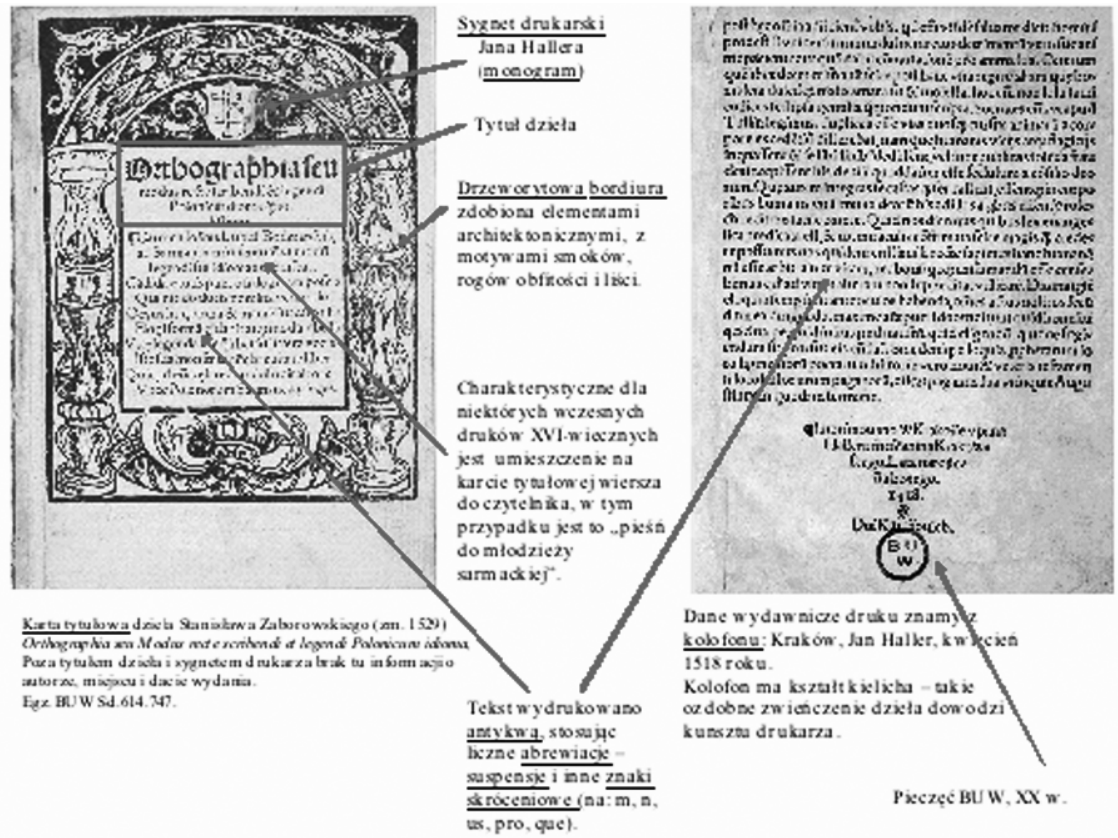

Il. 1. Proponowane objaśnienia morfologii wczesnego druku renesansowego

kach polskich, pełniła przez lata Biblioteka Narodowa ${ }^{8}$, gromadząc opisy do Katalogu Centralnego Starych Druków, w ramach prac prowadzonych przez Zakład Opieki nad Dawną Książką na zlecenie Ministerstwa Kultury. Uzyskany materiał jest dostępny w gmachu BN w formie kartkowego katalogu bibliograficznego - zawiera on informację o blisko milionie egzemplarzy starych druków znajdujących się w 150 bibliotekach. Brakuje natomiast syntetycznych danych o stanie liczbowym poszczególnych kolekcji, chociażby w postaci drukowanego informatora.

Proponowana zakładka „Zasoby starych druków dziś” mogłaby zawierać: nazwę instytucji, krótką charakterystykę znajdujących się w niej kolekcji starych druków, kontakt, godziny otwarcia i warunki dostępu oraz odesłanie do lokalnego katalogu. Chodzi tu raczej o zebranie w jednym miejscu skróconej informacji prowadzącej zainteresowanego głębiej za pośrednictwem odpowiednich linków, a nie szczegółowe przedstawianie zbiorów biblioteki. Niewątpliwie pomocna byłaby mapka ukazująca ilościowe rozmieszczenie starych druków w poszczególnych instytucjach w Polsce.

${ }^{8}$ Por. M. Zychowicz, Centralny katalog starych druków w Bibliotece Narodowej w Warszawie, Warszawa 1995. 
Ad. 4. „O badaniach nad dawną książką” lub: „Jak się opracowuje dawną książkęe?" Ponieważ mamy wrażenie narastającej przepaści pomiędzy: katalogującymi stare druki - historykami książki - bibliotekoznawcami sensu stricto - specjalistami z innych dziedzin wykorzystującymi w swej pracy stare druki, zasadne wydaje się przedstawienie specyficznej metody opracowania zabytku, jakim jest stary druk. Kto dziś korzysta z drukowanych katalogów starych druków? Czy, poza opracowującymi te zbiory, badacz innej specjalności nie ma kłopotu ze zrozumieniem stosowanych w nich skrótów? Proponujemy rozbiór tzw. „pozycji katalogowej”. Czy np. taki opis, sporządzony zgodnie z wszelkimi „zasadami sztuki”, nie budzi żadnych wątpliwości?

\section{GESNER Conradus}

4219. Bibliotheca Universalis sive Catalogus omnium scriptorum locupletissimus, in tribus linguis, Latina, Graeca et Hebraica...: opus novum et non bibliothecis tantum publicis privatisve instituendis nescessarium, sed studiosis omnibus... utilissimum...

Tiguri: apud Christ. Froschoverum, IX 1545 [rz.]. - [18, 8-ma cz.], 631, [1 cz.] k. ; $2^{\circ}$.

Adams G-516. BLC 123,458. CBN 59,922. BJ 16 G-326. VD-G 1698. Vischer C-350 (Gessner).

NB. Wzmianki o Janie Dantyszku (s. 411), Mikołaju Koperniku (s. 518). Def.: brak kk. 304-308, 374, 378, 392, 443-445, 502-504, 557-558, 594 (wycięte); kk. 367, 377, 379, 394, 396, 427, 627-631 zachow. we frg. Prow.: 1. [Stanisław Iłowski] - XVI w.

2. Ex Ilovianis 1613 - ręką A. Obrębskiego.

3. Inscriptus (przekreślone:), Haereticae (dalej tą samą ręką:) Catal[og]o Bibliothecae Collegij Łomzen[sis].

4. Święcki oraz Suchodolski - XVII w., na s. 193, tą samą ręką, czy prow.? Cenzura: Correctio huius libri permittit [ur] in Indice librorum prohibitorum oraz Purgata et Correcta. Obfite marginalia - oceny dzieła, komentarze do haseł. Wiele kart całkowicie lub częściowo wyciętych, wiele pokreślonych. W kolofonie po słowie „Finis” ręką Obrębskiego: A[nn]o 1617 die 8 Martij.

Opr.: papier, perg., resztki wiązań - XVI w.

Sd.602.835

Il. 2. Opis katalogowy edycji Bibliotheca universalis Konrada Gesnera, Zürich 1545, za: Katalog druków XVI wieku... por. przypis 9. 
Dlaczego np. wykropkowano tę, a nie inną część tytułu, gdzie wydrukowano dzieło, co oznacza [rz.], oraz inne, następujące dalej skróty? Czy na podstawie opisu możemy określić, jakiej wielkości jest książka, dlaczego cytata bibliograficzna jest uporządkowana w takiej, a nie innej kolejności, kim byli kolejni właściciele książki oraz co oznacza „papier” w opisie oprawy? Jaki jest powód umieszczenia w Nota Bene informacji o Janie Dantyszku i Mikołaju Koperniku? Owszem, istnieją entuzjaści katalogów bibliotecznych mający świetne rozeznanie w meandrach języka bibliotecznego, lecz przyznajmy, że jest to grupa szczególnie wyspecjalizowana $\mathrm{i}$ - chyba coraz rzadziej występująca. Powyższy opis pochodzi z katalogu drukowanego ${ }^{9}$; jednak obecnie najintensywniej przebiega opracowanie starych druków online, głównie do centralnego katalogu NUKAT (w listopadzie 2012 r. baza liczyła ponad 30 tys. rekordów). Najnowsza wersja „Formatu MARC21 rekordu bibliograficznego dla starych druków"10, która ukazała się w kwietniu 2011 r., zajmuje ponad sto stron szczegółowych instrukcji, uwzględniających rozliczne niuanse tak wymykającego się schematycznemu opisowi obiektu, jakim jest dawna książka. Produkt wyjściowy - rekord bibliograficzny w NUKAT - miewa różną jakość, uzależnioną głównie od, nazwijmy to, czynnika ludzkiego, czyli predyspozycji katalogującego. Bywa jednak niezwykle dopracowany, szczegółowy i przynoszący nowe ustalenia względem dotychczasowych katalogów, co wynika m.in. z obecnych możliwości wyszukiwawczych online, jak i z łatwości w komunikowaniu się z innymi bibliotekami posiadającymi opracowywaną edycję (również online). Ile nowego możemy znaleźć o starych drukach w katalogu NUKAT - to już inny temat. Pozostaje jednak pytanie, czy tworząc coraz bardziej wymagające standardy opisu bibliograficznego nie zgubiliśmy po drodze nienadążającego już za narastającą szczegółowością opisów - ich skromnego odbiorcy. Choć częściowemu zasypaniu tej przepaści miałoby służyć przybliżenie warsztatu pracy katalogującego oraz objaśnienie jej efektów. Przykładowo: w jaki sposób ustalamy rok wydania, kiedy jest on wyobrażony na karcie tytułowej w postaci liczby arabskiej, rzymskiej, hebrajskiej, chronostychu; obecny w przedmowie, liście dedykacyjnym lub kolofonie; gdy nie występuje w druku wprost, a o którym wnioskujemy np. z dat życia osób wymienio-

${ }^{9}$ Katalog druków XVI wieku w zbiorach Biblioteki Uniwersyteckiej w Warszawie, t. 4: F-K, pod red. H. Mieczkowskiej, materiał proweniencyjny oprac. pod kier. M. Cubrzyńskiej-Leonarczyk, Warszawa 2011, s. 228.

${ }^{10}$ Oprac. H. Mieczkowska, dostępny na stronie: http://centrum.nukat.edu.pl/images/stories/file/instrukcje_procedury/MARC_21/marc21_staredruki_110411.pdf [XI 2012]. 
nych w paratekstach. Przydatne byłoby także wyjaśnienie, czym jest i co zawiera hasło KHW (Kartoteki Haseł Wzorcowych), czym się różni wariant od wydania, dlaczego raz liczymy karty, a raz strony. Nie chodzi tu o tworzenie wyczerpującego przewodnika dla początkującego „katalogera"11, ale o objaśnienie na wybranych przykładach specyfiki opisu dawnej książki, rozwiązania pewnych jej zagadek, dzięki czemu stanie się bardziej przystępna, lepiej zrozumiała, bliższa. Przecież u zarania wszelkich reguł katalogowania nie leży chęć skomplikowania materii, lecz wręcz przeciwnie - jej sprecyzowania i uporządkowania.

Ad. 5. Zakładka „Jak i gdzie szukać informacji? Katalogi, bazy, portale" pełniłaby rolę swego rodzaju przewodnika po źródłach drukowanych, internetowych i dostępnych za pośrednictwem innych mediów, pomocnego w odnalezieniu poszukiwanego druku. Czytelnicy, odwiedzający oddziały starych druków, zjawiają się w nich głównie z potrzeby sięgnięcia do tekstu. Rzadziej chodzi o indywidualne cechy książki, których zbadanie rzeczywiście wymusza zajrzenie do egzemplarza - żaden mikrofilm ani skan nie pomogą w odczytaniu wywabionej proweniencji albo w ustaleniu filigranu, jakiego użyto $\mathrm{w}$ papierze. Ci, którzy potrzebują tekstu, a nie zależy im na bezpośrednim zetknięciu z książką, przeważnie prowadzili już poszukiwania w internecie i nie natknęli się na interesujący ich tytuł lub konkretną edycję. Prym wiedzie tu oczywiście wyszukiwarka Google; rzadko kto ma świadomość istnienia innych możliwości wyszukiwawczych i wiedzę na temat sprofilowanych baz danych. To nie zarzut, a raczej naturalna konsekwencja sytuacji, gdy nie istnieje żaden przewodnik pt. „Jak odszukać stary druk?”, a studia, nawet z zakresu informacji naukowej, nie dają wiedzy o tym, czym się np. różni baza VD 17 od Edit 16. Zatem to oczywiste, że w poruszaniu się po gęstwinie zasobów cyfrowych główną rolę gra przypadek.

W zakładce znalazłyby się linki do różnych katalogów, wraz z ich krótką charakterystyką. Od repozytoriów centralnych (polskie: kartkowy w Bibliotece Narodowej, drukowana bibliografia Estreicherów ${ }^{12}$,

${ }^{11}$ Służą temu instrukcje katalogowania oraz specjalistyczne podręczniki, jak np. wielokrotnie wznawiane Nauki pomocnicze historii J. Szymańskiego (ostatnie wyd. Warszawa 2009).

12 Tomy 12-35 Bibliografii polskiej - stulecie XV-XVIII, nie są oczywiście katalogiem centralnym starych druków sensu stricto, ale nadal są tak traktowane przez niektórych czytelników, uznających za aktualną zawartą w nich informację o egzemplarzach poszczególnych edycji. Istotne byłoby tu zwrócenie uwagi na różnicę pomiędzy postacią drukowaną Bibliografii a uaktualnioną bazą danych online (www.estreicher.uj.edu.pl), prowadzoną przez Centrum Badawcze Bibliografii Polskiej Estreicherów w UJ, zawierającą sigla bibliotek posiadających obecnie stare druki. 
wspomniany już wyżej NUKAT; europejskie: $\mathrm{HPB}^{13}$ ), poprzez katalogi poszczególnych bibliotek (kartkowe, drukowane, online) aż do katalogów zbiorczych, gromadzących informację o wszystkich zasobach, oraz multiwyszukiwarek, scalających wyszukiwanie z wielu instytucji. Osobną kategorię utworzą bibliograficzne bazy narodowe czy regionalne oraz katalogi poświęcone tylko inkunabułom lub drukom XVI-, XVII-, XVIII-wiecznym. Wskazano by, w jaki sposób wyfiltrować z katalogów poszukiwaną pozycję, czy to pod względem chronologicznym (często możliwe), czy tematycznym (rzadziej - opcja występująca głównie w katalogach anglosaskich) oraz określono, czy dane katalogi zawierają tylko opis wydania, czy też są wzbogacone w skany stron kluczowych bądź linki do postaci pełnotekstowej. W następnej kolejności zostałyby opisane biblioteki cyfrowe, portale informacyjne, wystawy wirtualne, bazy proweniencyjne, opraw, znaków wodnych, sygnetów drukarskich, grafiki. Wiadomo, że najchętniej docieramy do poszukiwanego obiektu lub informacji o nim nie wstając od klawiatury. Może jednak portal byłby okazją do przypomnienia o istnieniu i sposobach dotarcia do: mikrofilmów, płyt $\mathrm{CD}$, reprintów. Te ostatnie wydawano niegdyś z braku innych możliwości reprodukowania; obecnie powstają luksusowe edycje bogato wyposażonych artystycznie dawnych ksiąg - przykładem połączenia pięknej szaty graficznej i naukowego opracowania mogą być publikacje wydawnictwa Taschen ${ }^{14}$.

Na gruncie ogólnoeuropejskim rolę przekaźnika informacji o dziedzictwie kulturowym książki drukowanej pełni strona CERL-u ${ }^{15}$ (Consortium of European Research Libraries, wraz z katalogiem HPB), którego wielowątkowa działalność może stanowić wzór dla proponowanej polskiej strony informacyjnej. Choć witryna CERL-u funkcjonuje od lat 90-tych, wciąż można mówić, zwłaszcza w Polsce, o mozolnym przebijaniu się prezentowanej na jej łamach informacji do świadomości badaczy. Brakuje choćby tłumaczenia strony głównej na język polski i promocji portalu w środowiskach uniwersyteckich. Proponowany polski portal przybliżyłby działalność CERL-u, wskazał wątki szczególnie interesujące dla polskich badaczy, zwracałby uwagę na nowości na stronie Konsorcjum.

Ad. 6. „Literatura fachowa” - spis uszeregowany tematycznie, zawierający pozycje zarówno polskie jak i obcojęzyczne. Począwszy od

${ }^{13}$ Heritage of the Printed Book in Europe, 1455-1830, prowadzony przez CERL, zob. niżej.

${ }^{14}$ Np. M. S. Merian, Insects of Surinam, Köln - Los Angeles 2009; reprint bogato ilustrowanej publikacji z 1705 roku.

${ }^{15}$ Więcej na temat CERL por. artykuł M. Czapnik w niniejszym tomie. 
podręczników dotyczących historii drukarstwa, poprzez normy opisu katalogowego, pozycje poświęcone opracowaniu bibliograficznemu, proweniencyjnemu, opisowi oprawy itd. (tu odbiorcą byłby specjalista) aż do artykułów i monografii poświęconych poszczególnym aspektom badań nad dawną książką. Osobną grupę stanowiłyby czasopisma branżowe; cennym dodatkiem byłaby lista tekstów stanowiących „głos w dyskusji” na temat wszelkich spraw dotyczących dawnej książki (np. cezura czasowa starego druku, rola zbiorów specjalnych w bibliotekach polskich).

Ad. 7. „Konferencje, warsztaty, wydarzenia” - zebranie rozproszonej informacji o odbywających się, przede wszystkim w Polsce, ale nie tylko, wydarzeniach związanych z dawną książką. Znalazłaby się tu informacja o planowanych spotkaniach ogólnodostępnych (wystawy, pokazy, prelekcje, warsztaty z historii książki, Noc Muzeów), oraz tych, które są przeznaczone tylko dla specjalistów (konferencje, seminaria, warsztaty katalogowania).

Ad. 8. „Antykwariat” obejmowałby następujące zagadnienia: kwestie handlowo-prawne, kupno - czy i gdzie można kupować książki zabytkowe (antykwariaty, aukcje, targi, internet), na co zwracać uwagę przy zakupie (legalność: wywabione znaki własnościowe); sprzedaż, dary, legaty (gdzie można dokonać w Polsce wyceny, które biblioteki dokonują zakupów i przyjmują dary, a jeśli tak - według jakich kryteriów); wywóz starych druków za granicę (prawo, rola Biblioteki Narodowej); kradzieże; instytucje wspierające/sprawujące opiekę nad dziedzictwem narodowym, np. Narodowy Instytut Muzealnictwa i Ochrony Zbiorów - skrótowe przedstawienie roli i przedsięwzięć; bibliofilstwo a biblioteki; czasopisma i antykwaryczno-bibliofilskie strony online, konserwacja prywatnie posiadanych starych druków (linki do instytucji bądź firm, które się tym trudnią); wskazówki dotyczące warunków przechowywania.

Ad. 9. „Baza proweniencji” - będzie o niej mowa niżej.

Ad. 10. „Kontakt”. Niniejszy punkt może zaistnieć tylko przy założeniu ciągłego monitorowania portalu pod kątem zapytań kierowanych przez jego użytkowników (jak w przypadku forum dyskusyjnego). Specjalista mógłby udzielać porad czy też rozwiewać wątpliwości dotyczące dawnej książki bądź odpowiednio przekierowywać przesłane listy.

\section{Liber ultra textum}

Książka ręcznie drukowana, wytworzona w epoce nowożytnej, to nie tylko tekst i ilustracje wytłoczone na czerpanym papierze. Każdy, kto się z nią zetknął wie, że jej elementy składowe to również wszelkiego rodza- 
ju zapisy rękopiśmienne, znaki własnościowe oraz oprawa - czyli tzw. cechy indywidualne egzemplarza. Od momentu wydrukowania luźne karty dzieła zaczynały swój własny, jednostkowy żywot: albo były od razu oprawiane $\mathrm{u}$ introligatora i dopiero $\mathrm{w}$ takiej, ujednoliconej formie wystawiano książkę na sprzedaż, lub też klient kupował plik kart, i w zależności od gustu, funduszy i potrzeb, oprawiał je jako pojedyncze dzieło bądź w towarzystwie innych, pokrewnych tekstów (tzw. klocek złożony z kilku utworów). Już sam ten zabieg budzi ciekawość: dlaczego razem „bindowano", jak powiedzielibyśmy dziś, te, a nie inne tytuły? Niekiedy powodem była zbieżna tematyka, podobne daty wydania, ten sam autor, ale czasem zamysł, jakim się kierował czytelnik czy też właściciel książki, pozostaje nieodgadniony. W jakim stopniu informacja o połączeniu dzieł w jednej oprawie przedostaje się do katalogów bibliograficznych? Czy zwraca się w tym kierunku uwaga badaczy? Właśnie z powodu braku odpowiednich narzędzi badawczych temat ów pozostaje słabo rozpoznany.

Zarówno oprawa jak i wnętrze dawnej książki, poza tym, że stanowią teren do badań nad ich warstwą rękodzielniczą (filigrany, technika introligatorska, kroje czcionek, grafika ilustracyjna, rodzaje zdobień), są też źródłem dostarczającym niezwykle interesujących i często unikatowych świadectw użytkowania bądź czytania, pozostawionych przez dawnych posesorów.

Jeśli chodzi o notatki świadczące o recepcji wydrukowanego tekstu, to spotykamy zarówno drobne zaznaczenia (Nota bene, ,umankietowane" rączki ${ }^{16}$ ), pod-, za- i przekreślenia, interlinearne tłumaczenia lektur szkolnych (np. z greki na łacinę), uwagi do tekstu - w postaci lapidarnych określeń bądź obfitszych komentarzy, a nawet umieszczony na interfoliowanych kartach rękopiśmienny tekst sporządzony przez wyjątkowo aktywnego odbiorcę.

$\mathrm{Z}$ pozostawionych śladów czytelnictwa wynika jednakże, że rola książki nie kończyła się na przekazie treści i udostępnieniu życzliwych marginesów na uwagi. Relacja człowiek - nośnik tekstu, była kiedyś bardziej skomplikowana. Książkę odręcznie cenzurowano, stosując wobec niej szereg drastycznych zabiegów: zamazywanie, wycinanie, a nawet zaklejanie, czy zaszywanie nieprawowiernych fragmentów. Umieszczano w niej zaklęcia przeciw złodziejom - te żartobliwe i te serio, grożące ekskomuniką. Czyste karty ochronne zapełniano zapisami historycznymi,

${ }^{16}$ Owe błahe, wydawałoby się, symbole, są obecnie przedmiotem badań z pogranicza semiotyki i historii książki, por. np. W. H. Sherman, Used books. Marking Readers in Renaissance England, Philadelphia 2008. 
genealogicznymi, gospodarczymi, astronomicznymi, religijnymi. Zdarzają się sentencje i cytaty z różnych autorów (np. Coelum ad nos spectat: Coelum spectemus oportet || Nam Deus astra dedit Coelo; oculosque tibi ${ }^{17}$ ), recepty (np. koniam na kaszel ${ }^{18}$ ), lub np. takie wiersze, których autora, jak na razie, nie udało się zidentyfikować:

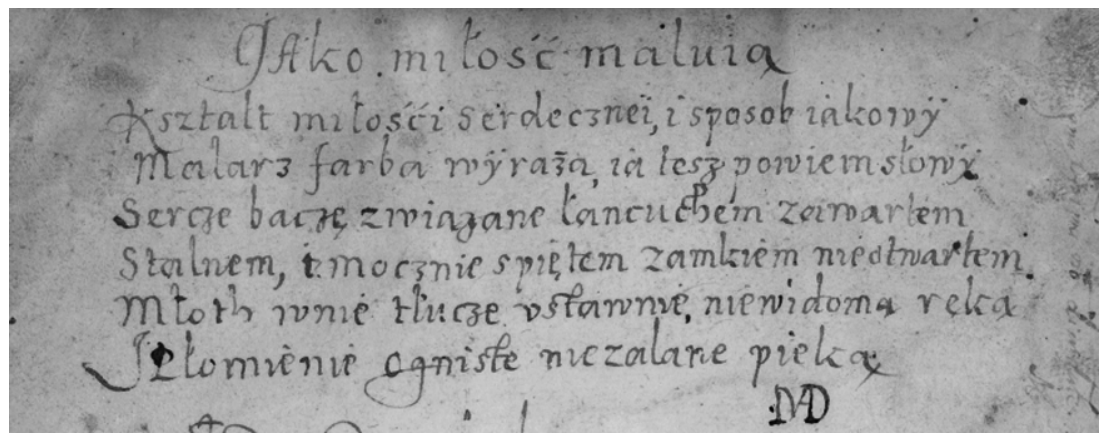

Il. 3. Wiersz sygnowany inicjałami M A D, zapisany na dolnej wyklejce egzemplarza Logicae compendium Crisostoma Javellego, Lyon 1579, BUW Sd.608.4306.

Nie miejsce tu na przegląd elementów rękopiśmiennych w książce drukowanej; ich wartość doceniali m.in. Aleksander Brückner, Jan Stanisław Bystroń, Kazimierz Piekarski czy Maria Sipayłł. Ciekawy artykuł na ten temat, zwłaszcza jeśli chodzi o typologię zapisków, napisała przed laty Anna Czekajewska-Jędrusik ${ }^{19}$. Chodzi tu raczej o zwrócenie uwagi na dwie sprawy. Po pierwsze, kwestia czasu poświęcanego przez bibliotekarzy na wydobycie tego materiału. Ogólnie rzecz ujmując, podstawowym zadaniem opracowujących książkę jest zredagowanie opisu bibliograficznego. Od momentu, kiedy rozpoczęło się katalogowanie online, raczej zwielokrotniają się naciski, aby rekordy starych druków wprowadzać z większą intensywnością, coraz szybciej i sprawniej. Zmieniły się standardy opracowania, narzędzia dostępu, skrócił czas dotarcia do informacji. Natomiast nie zmieniła się sama książka, pozostając tak samo zagadkowym, trudnym i czasami irytująco odpornym na zaszufladkowanie obiektem. Bibliotekarze zmagają się zatem głównie z tym, co w niej

${ }^{17}$ Epigram autorstwa Johna Owena, zapisany ręką jezuity Andrzeja Obrębskiego (XVII w.) na egzemplarzu M. Frytschiusa Meteororum... loci fere omnes, Nürnberg 1563, BUW Sd.608.4101.

18 BUW Sd.614.695.

19 A. Czekajewska-Jędrusik, Elementy rękopiśmienne w książce drukowanej, [w:] Ksiażka rękopiśmienna XV-XVII w., pod red. B. Bieńkowskiej (Z badań nad polskimi księgozbiorami historycznymi, 4), Warszawa 1980, s. 69-90. 
wydrukowane, a czas na uwzględnienie tego, co znajduje się w niej ponadto, zawsze jest niewystarczający. W niektórych, bardziej uprzywilejowanych pod tym względem bibliotekach, obowiązkiem pracowników jest pochylenie się również nad cechami indywidualnymi egzemplarzy; w większości instytucji ledwo udaje im się wyrobić tzw. normę wymaganą przy opracowaniu bibliograficznym.

Druga sprawa to reguły opracowania we wspomnianym wyżej centralnym katalogu NUKAT, z którym współpracują wszystkie znaczniejsze biblioteki naukowe posiadające stare druki ${ }^{20}$, poza, niestety, Biblioteką Narodową, posługującą się odrębnym systemem. Owe zasady nie pozwalają na umieszczanie w opisie katalogowym innych danych niż bibliograficzne - rolą NUKAT-u jest identyfikacja wydań i poinformowanie odbiorcy o lokalizacji egzemplarzy. Dopiero na poziomie katalogu lokalnego można rozszerzyć rekord o dodatkowe dane - ale to już sprawa regulowana indywidualnie przez poszczególne instytucje.

Trzeba tu zaznaczyć, że z problemem uwidocznienia danych pozabibliograficznych borykają się biblioteki na całym świecie. Wszędzie priorytetem jest skrótowa informacja pozwalająca na szybką lokalizację egzemplarza, a następnie umożliwienie dostępu do postaci pełnotekstowej umieszczonej we własnej bibliotece cyfrowej lub na stronach zewnętrznych, do których przekierowuje się za pomocą linków. Jednak podczas gdy zawartość katalogów zachodnioeuropejskich (np. niemieckich, francuskich, włoskich, holenderskich) uległa już znacznemu nasyceniu i uwaga opracowujących zwraca się stopniowo ku kolejnym zadaniom, sytuacja w Polsce jest nieporównywalna. Nadal jesteśmy na etapie skanowania katalogów kartkowych, natomiast budowanie opisów bibliograficznych w ramach NUKAT wymaga na tyle dużego nakładu pracy i jest tak czasochłonne, że nie ma na razie mowy o zasadniczej zmianie optyki, jak w przypadku innych krajów.

\section{Proweniencje}

Owo przeniesienie uwagi następuje przede wszystkim w kierunku proweniencji, czyli wszelkich znaków i zapisów własnościowych umieszczonych w książce przez dawnych właścicieli bądź czytelników. Jeszcze wiele lat przed nastaniem ery komputerowej pracownicy oddziałów starych druków, zdając sobie sprawę, jak istotna jest rejestracja materiału

${ }^{20}$ Wykaz wszystkich 127 bibliotek współpracujących z NUKAT: http://centrum.nukat.edu.pl/index.php?option $=$ com_nubbw\&layout $=$ pl\&Itemid $=143$. 
proweniencyjnego ${ }^{21}$, gromadzili go w odrębnych kartotekach, a niekiedy umieszczali w katalogach drukowanych. Pozostawał on zatem rozproszony, opracowany w różnym stopniu, praktycznie nieznany szerokiemu odbiorcy, od specjalistów prowadzących badania w tym kierunku wymagający wielu żmudnych kwerend. Często natknięcie się na ciekawą proweniencję było wyłącznie zaskakującym zrządzeniem losu. Gdy punktem dostępu jest opis bibliograficzny, a ściślej - gdy głównym zbiorem jest nazwisko autora lub tytuł dzieła, siłą rzeczy traci się z oczu inny duży zbiór - kolekcję książek należących do pojedynczej, historycznej osoby bądź instytucji. Do właściciela można wówczas dotrzeć tylko za pomocą indeksu umieszczanego na końcu katalogów drukowanych.

Przedstawiony wyżej opis książki Konrada Gesnera zawiera również wykaz proweniencji znajdujących się w egzemplarzu. Niektóre polskie biblioteki próbują powielić w lokalnych bazach online schemat opisu stosowanego w drukowanych katalogach, dołączając do danych bibliograficznych informację o byłych właścicielach. Wykorzystują w tym celu tzw. pola lokalne formatu MARC21. Zaznaczmy raz jeszcze, że nie chodzi o centralny katalog NUKAT, lecz o bazy poszczególnych bibliotek nasila się tendencja, aby wszelkie dane dotyczące egzemplarza umieszczać tylko w katalogach lokalnych, odciążając i tak już rozbudowany rekord bibliograficzny ${ }^{22}$. Taką praktykę stosuje m.in. Biblioteka Jagiellońska, Ossolineum, biblioteki uniwersyteckie we Wrocławiu i Poznaniu. Przyjrzyjmy się przykładowemu rekordowi z katalogu BJ.

Proweniencje podano tu zarówno w formie ujednoliconego hasła (Jan Chryzostom Bodzenta, Kameduli - Kraków), jak i in extenso w postaci widniejącej na druku. Chodzi o to, aby czytelnik mógł odnaleźć właściciela zarówno za pomocą formy ujednoliconej, jak i słów użytych w zapisie rękopiśmiennym lub innym znaku własnościowym. Jak widać, hasła posesorów w rekordach BJ nie są indeksowane.

${ }^{21}$ Próby metodycznych ustaleń w tym zakresie: K. Piekarski, $O$ zadania i metody badań proweniencyjnych, Przegl. Bibliot., 3:1929, z. 3, s. 388-415; B. Kocowski, Zadania $i$ metody badań proweniencyjnych $w$ zakresie starych druków, Przegl. Bibliot., 19:1951, z. 1/2, s. 72-84; M. Sipayłło, O metodzie badań proweniencyjnych starych druków, [w:] Z badań nad polskimi księgozbiorami historycznymi, t. 1, pod red. B. Bieńkowskiej, Warszawa 1975, s. 9-30. Ostatnio na wagę badań w tym zakresie w kontekście bibliotek wschodnich ziem Rzeczpospolitej zwróciła uwagę M. Pidłypczak-Majerowicz, Badania proweniencyjne w polsko-ukraińskich księgozbiorach, [w:] Kraków-Lwów. Ksiażki, czasopisma, biblioteki XIX i XX wieku, t. X, pod red. H. Kosętki, G. Wrony i G. Niecia, Kraków 2011, s. 341-349.

${ }^{22}$ H. Mieczkowska, Katalogowanie starych druków w Narodowym Uniwersalnym Katalogu Centralnym (NUKAT), „Roczniki Biblioteczne”, 53:2009, s. 213-214. 


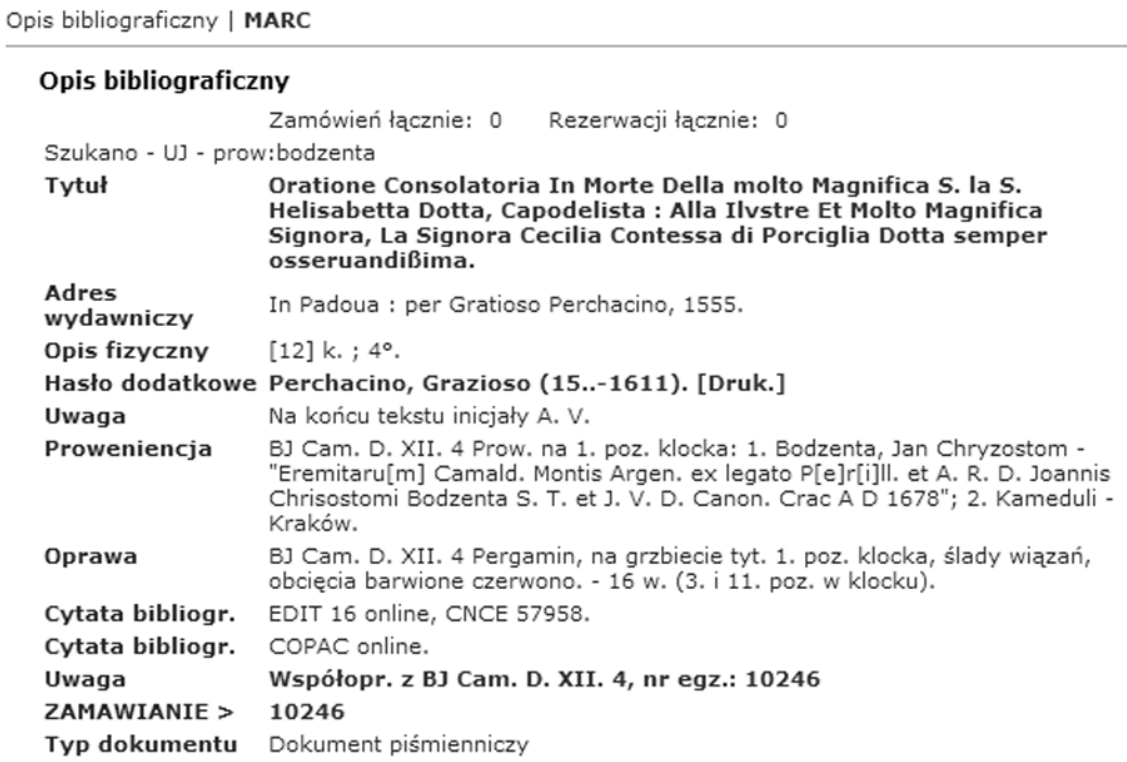

Il. 4. Rekord bibliograficzny BJ, zawierający informację

o proweniencji egzemplarza

To zaledwie jeden przykład. Każda z wymienionych bibliotek (oraz inne, a ich liczba wciąż rośnie) prezentuje dane dotyczące egzemplarza w nieco inny sposób: w odmiennych systemach - Virtua, Horizon, MAK, co się wiąże ze zróżnicowanym interfejsem, w polach, które się przeszukuje w różny sposób: za pomocą indeksów, kodów, słów kluczowych. Opisy mają różną konstrukcję, stopień szczegółowości i są tworzone zgodnie z zasadami stosowanymi tradycyjnie w danej bibliotece. Dla użytkownika jest to niewątpliwie duża niedogodność. I nawet pomijając wyżej wymienione mankamenty, nie zostaje spełniony podstawowy warunek: nie ma możliwości centralnego przeszukiwania proweniencji. Trzeba zajrzeć do każdego katalogu osobno i mozolnie wyłuskiwać informacje.

Według danych aktualnych we wrześniu 2010 r., w różnych katalogach komputerowych polskich bibliotek naukowych (dostępnych online i roboczych) znajdowało się ok. 120 tys. rekordów zawierających informację proweniencyjną ${ }^{23}$. Jest ona ponadto rozproszona $\mathrm{w}$ katalogach

${ }^{23}$ W dniach 14-15 IX 2010 odbyły się w Poznaniu warsztaty dla katalogujących stare druki, podczas których poruszono m.in. sprawę lokalizowania opisów proweniencyjnych oraz przedstawiono stan opracowania proweniencji w: BN, BJ, bibliotekach uni- 
kartkowych i drukowanych oraz w monografiach poświęconych poszczególnym kolekcjom. Niemożliwe jest przeniesienie tak różnorodnego materiału do jednego formularza komputerowego. W tej sytuacji jedynym rozwiązaniem wydaje się być utworzenie odrębnej bazy proweniencyjnej, budowanej od podstaw.

\section{Ogólnopolska baza proweniencji starych druków - inspiracje}

Czy mamy jakieś inspiracje ze świata? Niestety, jak na razie brak jakiejkolwiek narodowej bazy proweniencyjnej. Zwróćmy wszak uwagę na fakt, że wiele kolekcji zachodnioeuropejskich nie ulegało tak dramatycznym perturbacjom jak zbiory polskie. Nie dotyczyły ich wywóz$\mathrm{ki}$, polityczne przemieszczenia i bezładne rozproszenie. $\mathrm{Z}$ tego też powodu książki bywają prawie pozbawione śladów użytkowania bądź kolekcje w obrębie jednej biblioteki zawierają te same, powtarzalne we wszystkich woluminach znaki własnościowe, nie stanowiąc tym samym zbyt intrygującego materiału badawczego. Pewne przykłady jednak istnieją. Bibliothèque Municipale w Lyonie prowadzi od lat bazę „Provenance des livres anciens", administrowana przez Monique Hulvey z oddziału zbiorów specjalnych ${ }^{24}$. Baza zawiera ponad 1100 rekordów proweniencyjnych, obejmujących następujące kategorie: ujednolicone hasło właściciela, informacja o jego bibliotece, odpis i charakterystyka znaków własnościowych, zakres chronologiczny, skrótowe dane wydawnicze dzieła, sygnatura egzemplarza wraz z linkiem do opisu bibliograficznego w katalogu biblioteki liońskiej oraz bibliografia, na podstawie której sporządzono opis. Załączono również fotografie proweniencji.

Wyszukiwanie proste odbywa się tu przez wszystkie słowa z rekordu, a wyszukiwanie zaawansowane przez krzyżowe zestawienie wyżej wymienionych kategorii, oprócz danych bibliograficznych i literatury przedmiotu. Przy okienku każdej z kategorii można rozwinąć indeks proponowanych haseł.

wersyteckich w Poznaniu, Toruniu, Wrocławiu i Warszawie, Ossolineum oraz Książnicy Cieszyńskiej. Wtedy też został wysunięty postulat utworzenia odrębnej bazy proweniencji starych druków znajdujących się bibliotekach polskich. Por. R. WilgosiewiczSkutecka, Warsztaty opracowania starych druków - Poznań 2010, [w:] Biuletyn EBIB, 9/2010 (118).

${ }^{24}$ Por.: http://www.bm-lyon.fr/trouver/basesdedonnees/base_provenance.htm [XI 2012]. Zob. też: M. Hulvey, Il n'est plus à toi mais à moi..., „Gryphe. Revue de la Bibliothèque de Lyon”, 2 semestre 2003, numéro 7, s. 37-46 oraz R. Wilgosiewicz-Skutecka, Lyońska baza proweniencji - poznańskie marzenia, „Biblioteka”, 10 (19):2006, s. 201-207. 


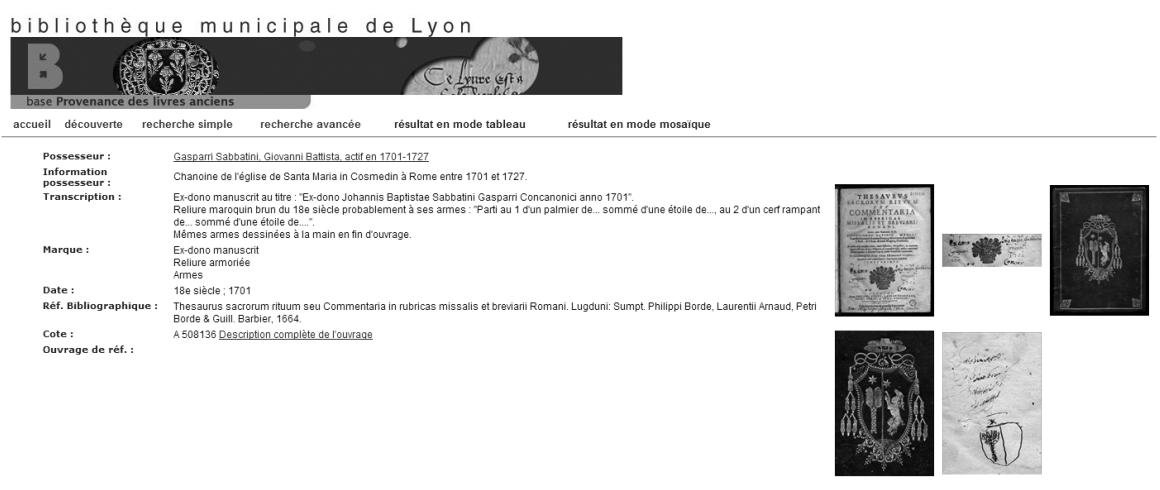

Il. 5. Przykładowy rekord proweniencyjny w bazie „Provenance des livres anciens”

Inny projekt to istniejąca od niedawna baza „Provenio”, powstała w Oddziale Rękopisów i Starych Druków Biblioteki Muzeum Narodowego w Pradze ${ }^{25}$, we wspólpracy z CERL. Celem projektu jest „stworzenie obowiązującej i funkcjonalnej metody katalogowania i opisu proweniencji książek" "26, a uzyskane rezultaty mają być czeskim narodowym wkładem do europejskich badań nad dziejami księgozbiorów. Na początkowym etapie, opracowanie obejmie tylko książki zgromadzone w Muzeum Narodowym w Pradze - są to m.in. kolekcje pochodzące z zamkowych i pałacowych książnic. W przyszłości baza ma stać się platformą otwartą dla instytucji współpracujących, narzędziem wspierającym badania nad bibliotekami osób prywatnych, rodzin i instytucji nowożytnych.

W rekordzie autorytatywnym właściciela przedstawiono informacje biograficzne, historię i stan obecny biblioteki oraz przykłady najczęściej występujących proweniencji, na podstawie których identyfikuje się posesora. Rekord zawiera linki do ikonografii związanej z właścicielem, do zdjęć znaków własnościowych oraz do listy opisów bibliograficznych egzemplarzy. Baza jest budowana w systemie MARC21.

Wyszukiwanie odbywa się nie tylko przez terminy proweniencyjne, ale również przez detale opisu bibliograficznego. Dzięki temu, odpowiednio zawężając poszukiwania, możemy się np. dowiedzieć, kim byli właściciele książek wydrukowanych w Wenecji w 1. 1500-1530.

\footnotetext{
${ }^{25}$ Por.: www.provenio.net

${ }^{26}$ Założenia wg materiałów (m.in. poster konferencyjny) udostępnionych przez dr Jaroslavę Kašparową, autorkę projektu.
} 
Biography ; historiography: Johannes Crato von Crafftheim studoval nejprve theologii ve Wittenbergu a posléze medicínu v Padově, púsobil jako městský lékař ve slezské Vratislavi a jako osobni lékar̆ tři císařú: Ferdinanda I., Maxmiliána Il. a Rudolfa Il. Maxmilián II. mu udẽlii palatinát (1568). V roce 1581 se odebral na odpočinek na své slezské panství Rückerts (Szczytna), kde nechal vystavět evangelický kostel a kam rovněž přestěhoval svou knihovnu. V roce 1583 se však opět stěhuje do Vratislavi av závěru života pomáhal ošetřovat nemocné pr̆i morové epidemii. Svou odbornou činnost zasvětil především studiu morové nákazy a zpứsobu jejího šîrení. Patřill $k$ jedné z nejvýznamnějšich osobností evropského humanismu. Udržoval čilý korespondenční styk s ostatními evropskými humanisty a pủsobil rovněž jako zprostř̌edkovatel kontaktủ mezi učenci.

\begin{abstract}
hovor̂i napřílad o jejím stěhováni z Prahy do Rückerts někdy v roce 1581 nebo krátce poté a že zde byla k dispozici protestantskému kazateli Christophu Prătoriovi. Knihovnu, která byla bezesporu rozsáhlá a múžeme předpokládat že měla více než jeden tisíc svazkủ, zdědil po Cratonově smrti jeho jediný syn Johannes Baptista Crato, který však sedm let nato zemřel a knihovna se dostala do rukou dnes neznámého majitele. Byla s největší pravděpodobností rozprodána a během tohoto prodeje nebo později od některého z pozděǰ̌š́ch vlastníkú koupil velkou část Cratonovy knihovny Otto mladší z Nostic, jejímž prostřednictvím se dochovalo v Nostické knihovně celkem 147 svazkủ převážně lékařšké literatury vydané většinou italskými nakladateli. V rámci jeho knihovny se dochovala rovněž kompletní Biblia regia vydaná v Antverpách Christophem Plantinem v letech
\end{abstract}

Provenance records description: Johannes Crato von Crafftheim užival především tři typů supralibros vyražených jak na předni tak na zadní desku knihy. Na přední desce knihy byl zobrazen jeho erb se jménem a titulaturou a postavením vypsanými po obvodě. Na zadní desce je vyobrazen Samson zabijejíí I lva s devizou: "IRAE MODERERIS ET ORI" A v některých př́ipadech rovněž s datací 1571. Na titulním listu se rovněž objevuje Cratonovo exlibris ve fomě podpisu, propletených iniciál "JC"; popř̆. $v$ podobě Cratonova jména v dativu: "Cratoni" Řadu knih identifikuji rovněž dedikace adresované Cratonovi a vepsané větš̌nou autory knih, současně Cratonovými kolegy y umění lékařském. Tak je tomu rovněž v př́padě pět knih dopisú Pierandrey Martioliho, která nese nejen Matrioliho dedikaci Cratonovi na titulním listu, ale rovněž obsáhlý dopis, v němž Martioli vypisuje Cratonovi všechny těžkosti a okolnosti, které provázely př̌ipravu edice tohoto díla. Některé knihy Ize rovněž identifikovat na základě specifické vízdoby vazby slepotiskovým krucifixem na přední desce.

Location of the book collection: Majorátní knihovna hrabat z Nostic a Rienecka (Knihovna Národního muzea)

Supplement:

Supralibros A - předni desk

Supralibros A - zadni deska

Supralibros 1570 - predni deska

Supralibros 1570 - zadni deska

Supralibros 1571 - prední deska

Supralibros 1571 - zadní desk

Cratonovo rukopisne exlibris: "Joh. Crato D.

Cratonovo rukopisné exlibris: "JCrato-

Cratonovo rukopisné iniciálové exlibris: "]"

Bibliography

ADB 4 (1876), S. 567-569

CŁOMBIOWSKI, Karol. W krẹgu czytelniczym humanistów wrocławskich. Odczyt wygłoszony na akademii dla uczczenia dzisięciolecia Biblioteki uniwersyteckiej we Wrocławiu dnia 18 czerwca 1955 r. Wroclaw, 1955, 5. 6-9.

CILLET, Johann Friedrich. Crato von Crafftheim und seine Freunde. Ein Bietrag zur Kirchengeschichte. Erster und Zweiter Theil. Frankfurt am Main, 1860-1861. KACZOROWSKI, Włodzimierz. Śląscy lekarze XV-XVII wieku. Żródła biograficzne do dziejów medycyny na Śląsku. In: Kwartalnik Opolski 42 (1996), Nr. 2. Opole, 1996, S. 53. SEKOWSKI, Roman. Herbarz szlachty śląskiej. Informator genealogiczno-heraldyczny, tom I A-C. Chudów, 2003, S. 401

1) SOUVISEJÍCI BIBLIOGRAFICKÉ ZÁZNAMY KNIH Z KNIHOVNY JOHANNA CRATONA Z CRAFFTHEIMU V NOSTICKÉ KNIHOVNĔ V PRAZE (KNIHOVNA NÁRODNIHO MUZEA)

2) SOUVISEJICI BIBLIOGRAFICKÉ ZÁZNAMY KNIH Z KNIHOVNY JOHANNA CRATONA Z CRAFFTHEIMU V HERZOGIN ANNA AMALIA BIBLIOTHEK, WEIMAR

Il. 6. Rekord właściciela w bazie „Provenio”.

Inna, dostępna od niedawna baza, to powstała w ramach CERL $M a-$ terial Evidence In Incunabula (MEI) ${ }^{27}$. Tu punktem wyjścia jest nie właściciel, lecz konkretne wydanie inkunabułu. Rekord bibliograficzny jest pobierany z katalogu ISTC (Incunabula Short Title Catalogue). Do niego są dołączane informacje o cechach indywidualnych egzemplarzy znajdujących się w różnych bibliotekach - pod tym kątem książki są opracowywane $\mathrm{z}$ autopsji przez pracowników tychże instytucji. Celem bazy jest poznanie recepcji i dystrybucji owej specyficznej grupy najwcześniejszych ksiąg.

Jak wynika z doświadczeń twórców każdej z wymienionych wyżej baz, podstawowym zadaniem jest opracowanie właściwej metody - decyzja co do konstrukcji bazy, ustalenie, co jest w niej punktem wyjścia, jakie są

${ }^{27}$ Por. niżej M. Czapnik, Zasoby informacyjne CERL źródtem do badań nad europejskim dziedzictwem piśmienniczym, s. 256. 


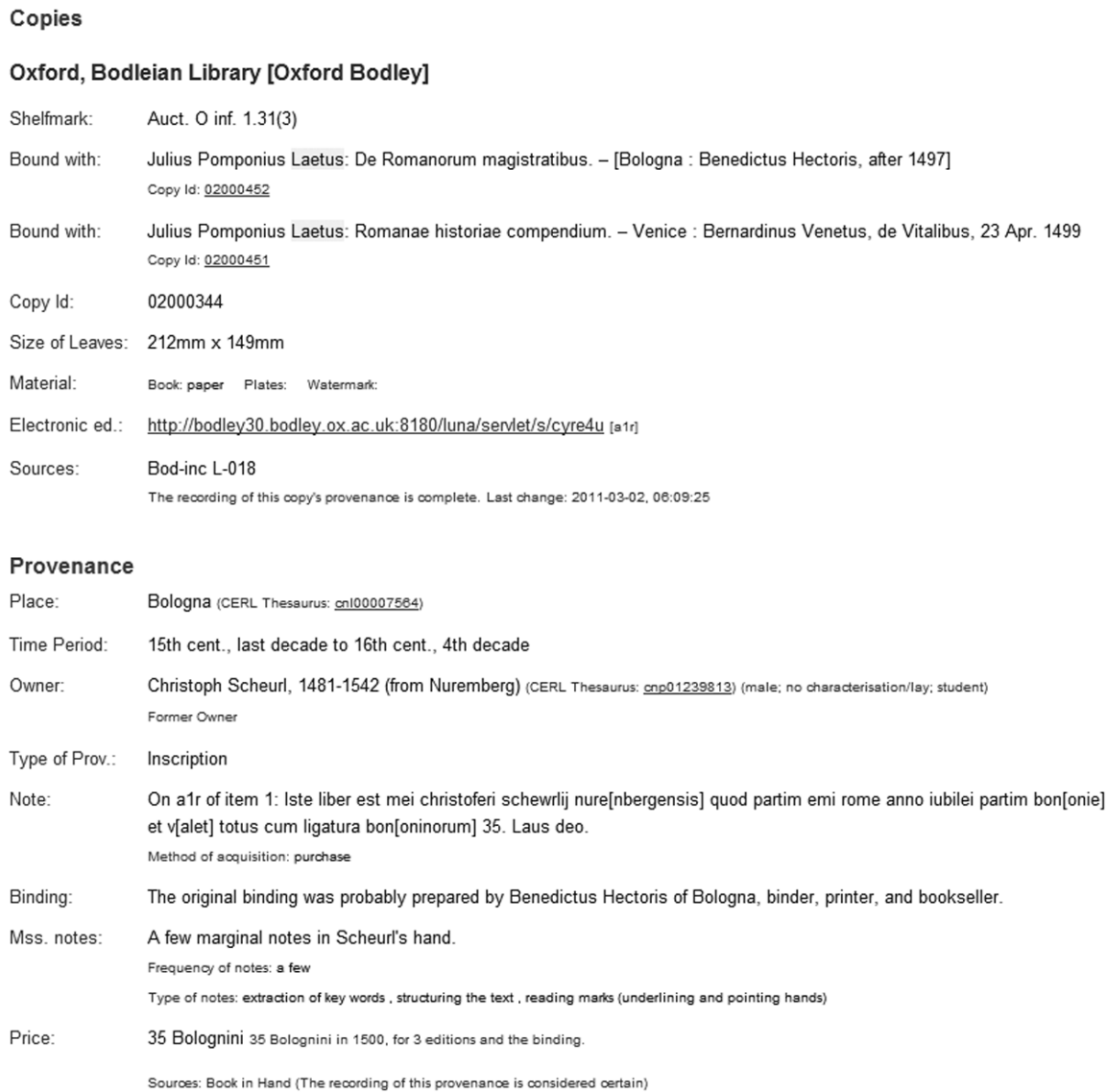

Il. 7. Opis proweniencji egzemplarza inkunabułu pochodzącego z Bodleian Library w Oksfordzie (projekt MEI)

jej założenia, cel oraz perspektywy. Następną, niezwykle złożoną i czasochłonną sprawą jest ustalenie obowiązującej terminologii. W sytuacji, gdy bazę tworzy się dla jednej biblioteki (przykład Lyonu), wystarczy zbudowanie słownika terminologicznego uwzględniającego specyfikę jednej kolekcji. Gdy planuje się przedsięwzięcie szersze, w którym mają uczestniczyć pracownicy wielu instytucji, gdzie funkcjonują różne tradycje opracowania proweniencji, sytuacja znacznie się komplikuje. Nie mówiąc już o tym, że docelowo ogólnopolska baza mogłaby zostać rozszerzona, po pierwsze: o proweniencje rękopisów (zgodne współistnienie druków i manuskryptów przez cały okres staropolski), po drugie: terytorialnie, o opisy proweniencji z dawnych polskich bibliotek znajdują- 
cych się obecnie na terenie Litwy, Białorusi, Ukrainy, a także Niemiec, Szwecji itd., po trzecie: o książki XIX-wieczne.

$\mathrm{Na}$ pierwszym etapie będzie zatem konieczne stworzenie szczegółowych (ale nie przytłaczających) zasad opisu proweniencji oraz uściślenie polskojęzycznej terminologii. Biorąc pod uwagę, że opisywany materiał ma międzynarodowy charakter, wielce przydatne, a nawet niezbędne będzie skonfrontowanie go $\mathrm{z}$ anglojęzycznymi słownikami powstałymi na potrzeby wyżej omówionych baz ${ }^{28}$.

Jeśli chodzi o hasła wzorcowe właścicieli: osób i instytucji, to istotna byłaby tu współpraca z NUKAT. Mamy w Polsce sytuację wyjątkową w porównaniu do innych krajów - centralny katalog bibliotek naukowych jest budowany od podstaw, a jego głównym założeniem jest „czystość" bazy. Kartoteka haseł wzorcowych podlega, podobnie jak rekordy bibliograficzne, modyfikacjom merytorycznym. W przypadku starych druków model współkatalogowania prowadzi dodatkowo do sytuacji nieustającej wzajemnej korekty rekordów, co skutkuje często wysoką jakością powstałych haseł i opisów. Obecnie w całej bazie NUKAT znajduje się ponad $3 \mathrm{mln} 300$ tys. rekordów KHW.

Najtrudniejszą sprawą od strony technicznej będzie linkowanie haseł proweniencyjnych $\mathrm{z}$ opisami bibliograficznymi egzemplarzy znajdujących się w różnych bibliotekach (czy również z NUKAT?). Jak była mowa wyżej, katalogi lokalne są prowadzone w różnych systemach, które cyklicznie poddawane są migracjom do nowych wersji. Ulega wtedy zmianie ich adres dostępu (URL). W efekcie prowadzące do zmodyfikowanych stron linki mogą stać się nieaktywne.

Zupełnie innym problemem, natury legislacyjnej, może być niechęć niektórych bibliotek do ujawniania proweniencji księgozbiorów należących przed 1939 r. do osób, których spadkobiercy obecnie mogą rościć do nich prawo własności. Brak regulacji prawnych prowadzi do sytuacji, gdy instytucja posiadająca zabytkowy księgozbiór, w wyniku roszczeń majątkowych, traci do niego prawa. Należy pamiętać, że to istotny czynnik, hamujący w Polsce przez dziesięciolecia publikowanie

${ }^{28}$ Słownik kodów do wyszukiwania zaawansowanego oraz instrukcja dla katalogujących wraz ze słownikiem stosowanej terminologii stworzony na potrzeby MEI przez Cristinę Dondi (University of Oxford), dostępny na stronie CERL (w jęz. angielskim i włoskim): http://www.cerl.org/help/incunabula/main. Materiał opracowany przez J. Kašparovą dla „Provenio” i M. Hulvey dla „Provenance des livres anciens” również jest dwujęzyczny: czesko-angielski i francusko-angielski. Por. też podręczniki: D. Pearson, Provenance research in book history, London 1994 oraz E. Barbieri, Guida al libro antico. Conoscere e descrivere il libro tipografico, Firenze 2006, rozdział: Descrizione dell'esemplare na s. 135-142. 
informacji o proweniencjach książek pochodzących z tzw. Ziem Odzyskanych.

Kończąc ten przegląd możliwości i trudności wspomnijmy o przedsięwzięciu, w którym od września 2012 bierze udział Gabinet Starych Druków BUW i które prawdopodobnie stanie się poligonem doświadczalnym dla opracowujących dawną książkę, przed powstaniem ewentualnego większego repozytorium. Chodzi o projekt badawczy „Dziedzictwo kulturowe po klasztorach skasowanych na ziemiach dawnej Rzeczpospolitej oraz Śląsku w XVIII i XIX w.: losy, znaczenie, inwentaryzacja" 29 , realizowany przy finansowym wsparciu Narodowego Programu Rozwoju Humanistyki pod egidą Ministerstwa Nauki i Szkolnictwa Wyższego. Do witryny portalu zostanie dołączona baza online: „Biblioteki po skasowanych klasztorach: historia, znaki własnościowe, źródła”. Znajdą się tu adnotowane hasła książnic z dołączonym materiałem źródłowym: zdjęciami zapisów i znaków proweniencyjnych.

Zgodnie z przygotowanym przez GSD BUW schematem hasła, obejmie ono materiał zgrupowany w trzech strefach: 1) informacja o bibliotece, 2) ilustracje, 3) źródła. W pierwszej strefie znajdą się m.in. różne formy nazw bibliotek klasztornych używane w zapisach i znakach własnościowych oraz syntetycznie ujęta historia i charakterystyka biblioteki (poszczególne etapy jej rozwoju, informacja o nabytkach i ubytkach, postaciach $\mathrm{z}$ nią związanych). W strefie ilustracji zostaną umieszczone zdjęcia wybranych znaków proweniencyjnych, z odpisem ich treści i ewentualnym komentarzem. Natomiast w strefie źródeł znajdzie się informacja o dawnych katalogach i inwentarzach oraz o nowszej literaturze, na podstawie której sporządzono hasła.

Może to i dobrze, że dwa duże projekty: SYNAT i Kasaty Klasztorów, zbiegły się w czasie. Jest to szansa na ujednolicenie ustaleń dotyczących opracowania proweniencji i jednocześnie niedublowanie pracy (linkowanie haseł bibliotek klasztornych $\mathrm{z}$ bazą ogólnopolską). Miejmy nadzieję, że polska baza proweniencji ujrzy światło dzienne, a w ramach obu przedsięwzięć uda się wypracować spójne i czytelne zasady tworzenia opisu, powstałe dzięki efektywnej współpracy międzybibliotecznej.

Dla dopełnienia tematu postawmy na koniec pytanie, analogiczne do widniejącego na wstępie. Komu jest potrzebna baza proweniencji? Poszukiwania proweniencyjne to praca polegająca na nieustającym „byciu na tropie" i dokonywaniu odkryć. Zdarza się odczytywanie zaszyfrowa-

${ }^{29}$ Por. www.kasaty.pl 
nych zapisów, a praca z lampą ultrafioletową przy wyblakłych bądź celowo wywabionych zapisach to właściwie codzienność. Towarzyszy temu ponadto wzruszające uczucie przywracania cieni do życia - szukamy w źródłach odczytanego nazwiska i cieszymy się znajdując potwierdzenie, że „Stanislaus ...strzinensis artium et philosophiae baccalaureus" pochodził z Kostrzyna i rzeczywiście był bakałarzem Akademii Krakowskiej w 1583 roku.

W bazie mógłby się znaleźć się link poświęcony detektywistycznym zagadkom, skupiający nieodczytane, nierozszyfrowane, nieokreślone znaki proweniencyjne. Mógłby on stanowić zbiór ciekawych problemów, zachęcających do historycznych poszukiwań. Ujawniłby się tym samym praktyczny wymiar badań historycznych, w które każdy może wnieść swój wkład ${ }^{30}$.

Trudno przewidzieć wszystkie potrzeby i odbiorców bazy proweniencyjnej. Z jej zasobów mogłyby skorzystać np. osoby prowadzące prywatne i instytucjonalne poszukiwania genealogiczne. W przypadku ustalenia rzeczywistych konotacji postaci występujących w proweniencjach współpraca $\mathrm{z}$ nimi mogłaby $\mathrm{w}$ interesujący sposób uzupełniać wiedzę o dawnych właścicielach.

Baza mogłaby również służyć rozpowszechnieniu wiedzy o aktualnych, obecnie używanych $\mathrm{w}$ bibliotekach znakach proweniencyjnych (wygląd i rozmiary pieczęci, sygnatury, charakterystyczne oprawy). Bibliotekarze dokonujący zakupów na aukcjach bądź za pośrednictwem innych źródeł mogliby łatwiej zapobiegać ewentualnym próbom paserstwa; podobnie antykwariusze zyskaliby pomoc $\mathrm{w}$ identyfikacji pochodzących $\mathrm{z}$ bibliotek woluminów ${ }^{31}$. Opracowujący stare druki zyskaliby również pierwszorzędne narzędzie do szybszego ustalania proweniencji poprzez porównywanie zapisów, wzajemne konsultacje i korektę.

Najwięcej korzyści dostrzeże oczywiście historyk książki. Księgozbiory z terenów dawnej Rzeczypospolitej były w przeciągu wieków poniewierane, przemieszczane, unicestwiane. To, co zostało, rozsiane w insty-

${ }^{30} \mathrm{Tu}$ mogą pojawić się wątpliwości co do braku kompetencji internautów. Nasuwa się tu skojarzenie z projektem NASA, aby włączyć w obserwacje astronomiczne internetowych amatorów. O dokonanych odkryciach można przeczytać w serwisie planethunters.org. Por. również badania tygodnika „Nature” porównujące ilość błędów występujących w artykułach Wikipedii i Encyclopaedia Britannica, J. Giles Internet encyclopaedias go head to head, „Nature” 438(7070), 15 Dec. 2005, s. 900-901.

31 Por. bazę książek utraconych (Missing books), wraz ze zdjęciami znaków identyfikujących, opublikowaną na stronie Królewskiej Biblioteki w Danii: http://wayback.kb.dk:8080/wayback-1.4.2/wayback/20100107153228/http://www2.kb.dk/kb/missingbooks//index-en.htm 
tucjach i kolekcjach prywatnych na całym świecie, stanowi cenne i interesujące świadectwo kultury dawnych wieków. W wyniku tego rozproszenia, oraz dodatkowo, zniszczenia źródeł, żadna monografia dawnej polskiej biblioteki nie może poszczycić się kompletnością danych. Nawet żmudne kwerendy i podróże do oddalonych od siebie instytucji nie pozwalają na osiągnięcie zadowalającego rezultatu. Wirtualne scentralizowanie materiału proweniencyjnego byłoby szansą na choć częściową rekonstrukcję dawnych kolekcji. Na przywrócenie utraconej pamięci. 